\title{
Pore Pressures and Strains After Repeated Loading of Saturated Clay
}

\author{
NyAL E. WILSON AND JOHN R. GREENWOOD \\ Department of Civil Engineering, McMaster University, Hamilton, Ontario L8S $4 L 7$ \\ Received September 4, 1973 \\ Accepted January 11, 1974
}

Repeated and sustained loading tests on undrained samples of normally consolidated lacustrine clay are used to prove the existence of a relationship between pore water pressures and axial strains.

The behavior of the clay is studied by investigating the pore pressure and strain responses under repeated loading, and comparing them with the responses from the more usual sustained loading. Samples under repeated loading fail at a stress below the compressive strength of the material as obtained from a standard strength test.

It has been shown that, for a repeated stress level below a critical value a nonfailure equiiibrium state is reached, closed stress-strain hysteresis loops occur and the soil behavior is essentially elastic. For a repeated stress above the critical value, the effective stress failure envelope is reached and each loading cycle leads to further nonrecoverable deformations and ultimate failure.

The pore pressures and axial strains produced by loading may be divided into recoverable and norirecoverable components; both components of pore water pressure are linearly related to the axial strain provided the sample is not close to failure and there is a gradual increase in axial strains and pore pressures with time. This relationship is explained by a simple mechanistic picture.

The pore pressures due to the application of a shear stress may be considered as a combination of an elastic recoverable component, due to the elastic response of the soil grain structure, and a plastic nonrecoverable component due to a partial collapse of the grain structure with subsequent transfer of stresses from the failed grain contacts to the pore water. There are coresponding axial strains occurring due to the elastic response of the soil grain structure and the partial collapse of the structure.

Experimental proof of the pore pressure versus strain relationship is presented by mcans of a series of loading tests on normally consolidated lacustrine silty clay samples tested under undrained triaxial conditions.

Des essais non drainés de changement à charge constante ou alternée sont utilisés pour démontrer l'existence d'une relation entre pressions interstitielles et déformations axiales.

Le comportement de l'argiie est étudié par observation des variations de pressions interstitielles et des déformations sous l'influence de charges alternées et par comparaison de ces variations avec celles qui se produisent dans les essais classiques à charge constante. Les échantillons soumis a des charges alternées atteignent la rupture pour une contrainte inférieure à la résistance en compression du matériau telle qu'obtenue à partir d'essais standards.

Il a été établi que, pour un niveau de contrainte alternée inférieur à une valeur critique, un état d'équilibre stable est atteint auquel correspondent des courbes effort-défornation en forme de boucles d'hysterisis fermées et un comportement essentiellement Elastique du sol. Pour une contrainte aliernée supérieure à la valeur critique, l'enveloppe de rupture en contraintes effectives est atteinte et chaque cycle de chargement conduit à des déformations non réversibles additionnelles et à la rupture finale.

Les pressions interstitielles ế les déformations axiales produites lors du chargement peuvent être divisées en composantes réversibles et non réversibles; les deux composantes de la pression intersititelie sont reliées linéairement à la déformation axiale à condition que l'échantillon ne soit pas à proximité de la rupture, et on observe une augementation graduelle des déformations axiales et des pressions interstitielles en fonetion du temps. La relation est expliquée par un modèle mécanique simple.

Les pressions interstitielles dues à l'application d'une contrainie de cisaillement peuvent être considérées conme la combinaison d'une composante éiastique réversible, due au comportement élastique de la structure du sol, et d'une composante plastique non réversible due à l'effondrement partiel de la structure avec transfert subséquent des con- 
traintes des contacts granulaires détruits vers l'eau interstitielle. Des déformations axinles correspondantes se produisent, dues au comportement élastique de la structure et à l'effondrement partiel de cette structure.

La preuve expérimentale de la relation pressions interstitielles-déformations est présentée à partir d'une série d'essais de chargement d'échantillons d'argile silteuse lacustre normalement consolidée en condition triaxle non drainée.

[Traduit par le journal]

It has long been realized that the undrained strength of clays is greatly affected by the testing technique. Casagrande and Wilson (1951) showed that for most clay soils the strength decreases in proportion to the logarithm of the time to failure. The pore water pressures at failure have been shown to increase with increasing duration of test (Bjerrum et al. 1958; Crawford 1959). Creep tests were used by Walker (1969) to obtain a better understanding of clay behavior in terms of an effective stress-strain relationship. Two relationships were developed between the variables but it was not possible to clearly define the functions relating pore pressures and strains to effective stresses. In this research, the problem is approached in a basic manner by the comparison of repeated and sustained loading tests on saturated, normally consolidated triaxial specimens in the undrained state.

The first complete study of repeated loading of a saturated clay with pore pressure measurements was carried out by Sangrey et al. (1969); the load in these tests was applied gradually over a period of hours to enable pore water pressure equalization to take place. It was concluded that there exists a critical level of repeated stress; if the repeated stress is below the critical level, a nonfailure equilibrium state is reached and closed stress-strain hysteresis loops are recorded with the final soil behavior essentially elastic. Above the critical stress level, the effective stress failure envelope is reached and each loading cycle leads to further nonrecoverable deformations and ultimate failure.

The results outained from this work indicate that no positive equilibrium state exists. For any value of stress applied to an undrained saturated clay, the pore pressures and strains continue to increase with time in a manner similar to the drained process of secondary consolidation.

The concept of a pore water pressure strain relationship was developed by Lo (1969). It was shown mathematically that the pore pressure induced by an applied stress may be expressed as a sole function of major principal strain. The results of these tests are in agreement with this concept.

Lo described the following hypothetical mechanism for the development of the pore pressures in normally consolidated clays. With the application of an external shear stress the microscopic strain in a particular direction is composed of the summation of three microscopic components:

(i) the elastic deformation of the soil skeleton;

(ii) the elastic deformation of the soil particles; and

(iii) displacements at the points of contact between clay particies.

Elastic deformation of the soil particle is small compared with that of the soil structure and is generally ignored. The elastic deformation of the soil skeleton produces pore water pressures which are recoverable when the applied stress is removed. However the recovery is time dependent due to the viscous medium of the adsorbed water. According to elastic theory the recoverable or elastic pore pressures $\left(\Delta U_{\mathrm{p}}\right)$ are given by the average of the applied principal total stresses:

$$
\Delta U_{\mathrm{e}}=\frac{1}{3}\left(\Delta \sigma_{1}+\Delta \sigma_{2}+\Delta \sigma_{3}\right)
$$

The permanent deformations and pore pressures are caused by displacements at the grain to grain contacts under stress. Immediately after the load application, deformation occurs throughout the soil skeleton which produces the elastic or recoverable pore pressures while sliding at some of the grain contacts produces plastic nonrecoverable deformations. As a result of sliding at contacts which have failed, permanent deformation occurs. As each contact fails, part of the stress originally carried at the contact is transferred to the pore water with an increase in pore water pressure and part to the neighboring stable contact points with an increase in contact stresses. Hence, under con- 
stant applied stresses, both deformations and pore pressures progressively increase with time.

Lo states that, from this hypothesis of stress transfer at contacts, it is apparent that the induced pore pressures and strains are intimately related.

The combined pore pressures $(\Delta U)$, due to the application of a shear stress, are therefore made up essentially of an elastic recoverable component $\left(\Delta U_{\mathrm{e}}\right)$ and a plastic nonrecoverable component $\left(\Delta U_{\mathrm{p}}\right)$ due to failure of the bonds at contacts between the soil particles.

$$
\Delta U=\Delta U_{\mathrm{e}}+\Delta \boldsymbol{U}_{\mathrm{p}}
$$

The combined axial strain $\left(\Delta_{\epsilon}\right)$ due to an applied shear stress is similarly composed of an elastic recoverable component $\left(\Delta \epsilon_{\mathrm{e}}\right)$ and $\mathrm{a}$ plastic nonrecoverable component $\left(\Delta \epsilon_{\mathrm{p}}\right)$

$$
\Delta \epsilon=\Delta \epsilon_{\mathrm{e}}+\Delta \epsilon_{\mathrm{p}}
$$

\section{Experimental Techniques}

The soil used was a normally consolidated lacustrine clay from Hamilton, Ontario. Undisturbed samples were taken from a depth of $40 \mathrm{ft}(12.2 \mathrm{~m}$ )

\begin{tabular}{|c|c|}
\hline Atterberg limits & $\begin{array}{ll}\text { P.L. } & \text { P.I. } \\
20 & 14\end{array}$ \\
\hline Natural water content & $25-27 \%$ \\
\hline Specifie gravity of soil grains & 2.73 \\
\hline Sensitivity & $3-4$ \\
\hline Grain size $D_{00}$ & 0.003 in. $(0.005 \mathrm{~cm})$ \\
\hline Grain size $D_{10}$ & $\begin{array}{l}0.0001 \text { in. }(0.00025 \mathrm{~cm}) \\
\text { (approx.) }\end{array}$ \\
\hline Clay sizes & $8 \%$ \\
\hline
\end{tabular}
using large diameter $(5-i n .(12.7-\mathrm{cm}))$ sampling tubes.

Coefficient of consolidation

cefficient of volume compressibility

$$
C_{\checkmark}=3.0 \times 10^{-4} \mathrm{~cm}^{2} / \mathrm{s}
$$

$$
M_{v}=1.2 \times 10^{-5} \mathrm{~cm}^{2} / \mathrm{g}
$$

\section{Coefficient of permeability}

$$
K=3.6 \times 10^{-8} \mathrm{~cm} / \mathrm{s}
$$

The triaxial testing was carried out on WykehamFarrance equipment with compensating mercury pots. Porc pressures were measured by a Statham pressure transducer in the base of the cell: readings were recorded on a temperature compensated, digital voltmeter.

The soil samples were trimmed to 1.4 in. $(3.6 \mathrm{~cm})$ diameter and $2.8 \mathrm{in} .(7.1 \mathrm{~cm})$ length and surrounded by a saturated slit filter paper with porous stones at the top and bottom. The use of the filter paper shortened the drainage path during consolidation and enabled an average reading of pore water pressure to be recorded at all times. Drainage and pore water pressure measurements were taken from the base of the sample.
The samples were enclosed in two rubber membranes, with a layer of silicone grease between them.

All samples were isotropically consolidated under a cell pressure of 70 p.s.i. $\left(4.9 \mathrm{~kg} / \mathrm{cm}^{2}\right)$ against a back pressure of 20 p.s.i. $\left(1.4 \mathrm{~kg} / \mathrm{cm}^{2}\right)$ giving a net isotropic consolidation pressure of 50 p.s.i. $\left(3.5 \mathrm{~kg} / \mathrm{cm}^{2}\right)$; the use of a back pressure improved saturation of the sample. The samples were allowed to consolidate for at least 4 days then they were subjected to one of the following tests. This consolidating procedure was selected to produce similarity of samples for the research program. The behavior may duplicate that for an over-consolidated soil and it is recognized that changes in some soi] properties (e.g. sensitivity) may result.

\section{Strength Test}

This was a standard consolidated undrained test (CU or ' $R$ ' test) in which the axial strain was increased at an essentially constant rate of $0.055 \% / \mathrm{min}$ to a maximum strain of $15 \%$. The compressive strength $\left(\sigma_{3}\right)$ was obtained from this test.

\section{Repeated Loading Test}

The repeated load was applied by a motorized device which lifted a weight on a platform attached to the ram of the triaxial cell. The repeated axial deviator stress $\left(\sigma_{\mathrm{r}}\right)$ is expressed as a proportion of the compressive strength obtained from the standard strength test $\left(\sigma_{n}\right)$.

The durations and intervais of the loading were 1 min for all the repeated lcading tests. Variation of the duration and interval has been shown to affect the behavior of the soil (Seed and Chan 1961) but these effects are not considered in this work.

\section{Remolded Tests}

Some of the natural clay was completely remolded at the liquid limit, then isotropically consolidated to approximately the same water content as the natural 'undisturbed' consolidated samples; the net consolidation pressure required for this was 45 p.s.i. $(3.2 \mathrm{~kg} /$ $\mathrm{cm}^{2}$ ). Strength tests were carried out on the remolded samples.

\section{Experimental Results}

When the deviator stress is applied to the clay samples there is an immediate straining of the soil and an increase in the pore pressures. The pore water pressures and axial strains continue to increase with time under the action of repeated loading. The increases in pore pressures and axial strains for a typical repeated loading test are illustrated in Fig. 1.

The immediate increase in the pore pressure and axial strain observed on first application of the load may be attributed to the elastic compression of the soil structure. The pore pressures and axial strains continue to increase until the load is removed. On removal, the pore 


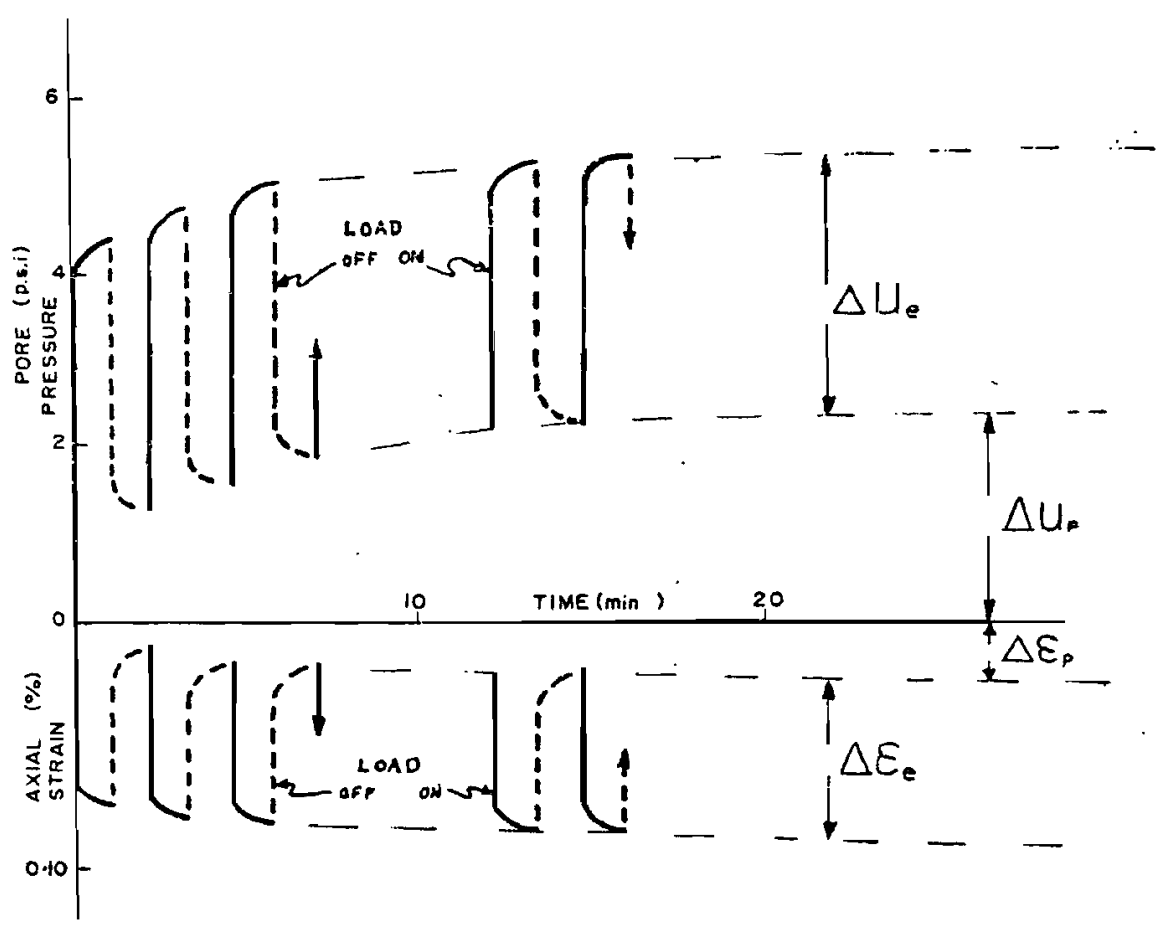

Fro. 1. Pore pressures and strains generated by repeated loading.

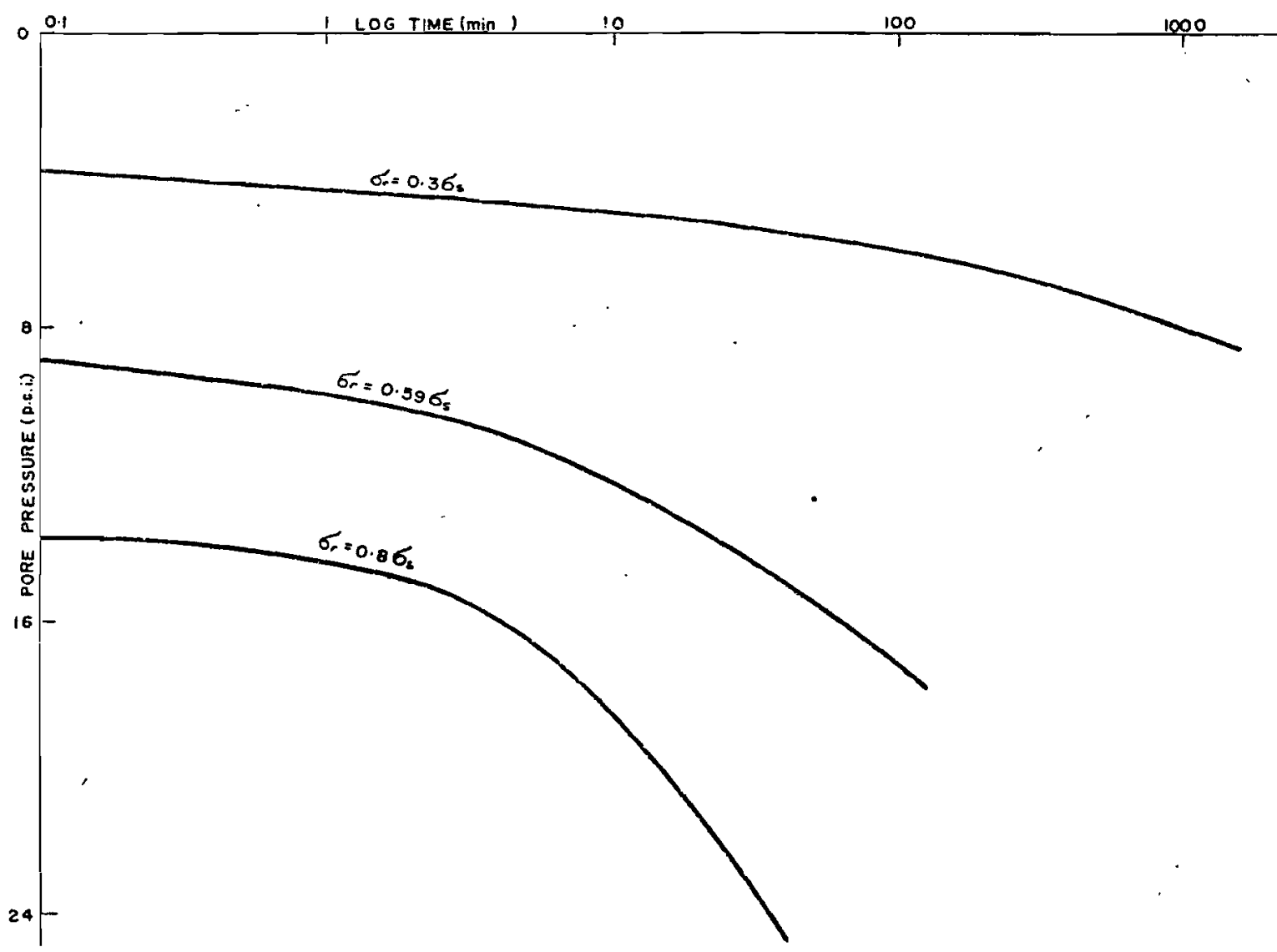

Fig. 2. Pore pressures under repeated loading. 


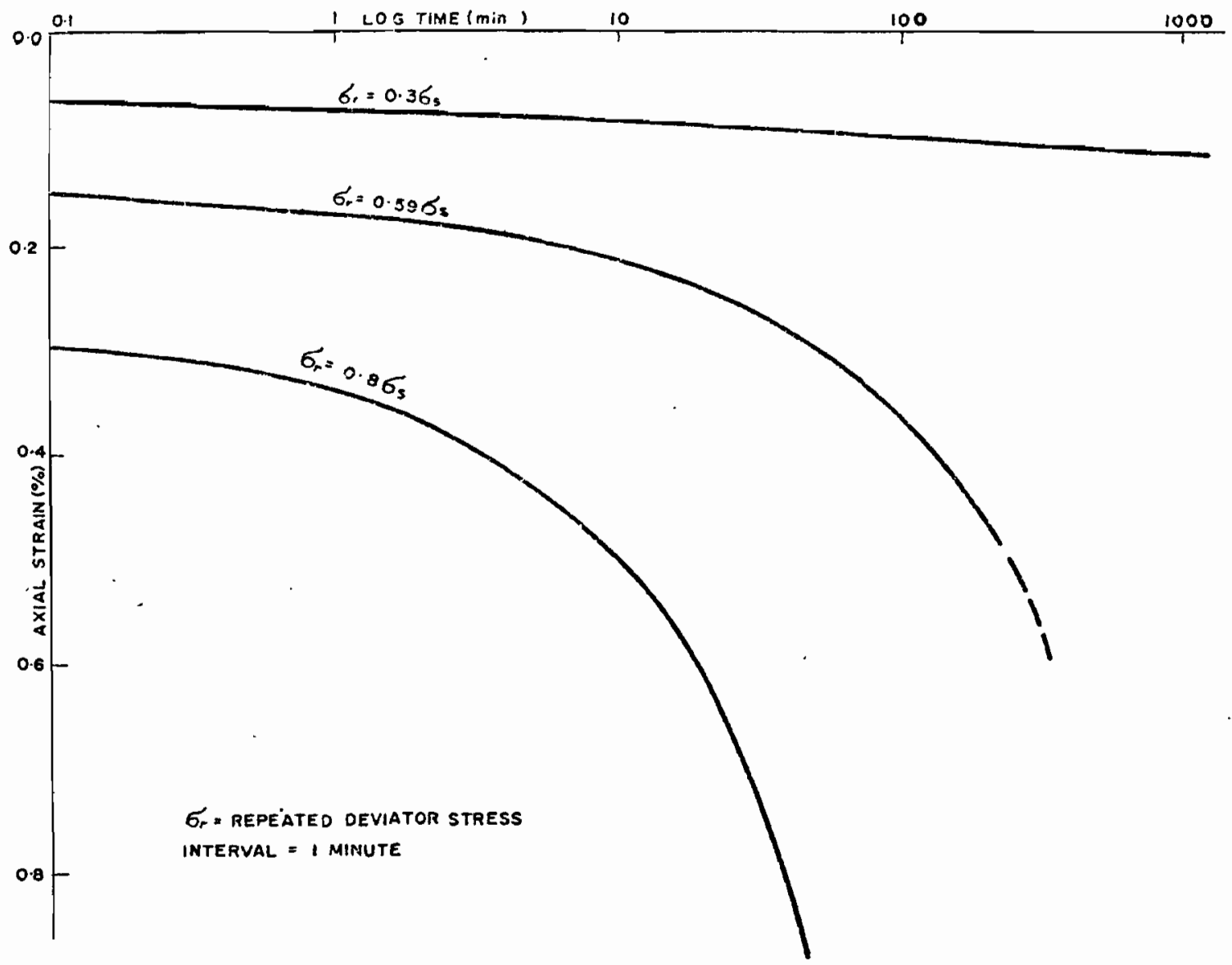

Fro. 3. Strains under repeated loading.

pressures and axial strains decrease with the elastic recovery of the soil structure but there remains a residual, nonrecoverable pore pressure component $\left(\Delta U_{\mathrm{p}}\right)$ and a residual, nonrecoverable strain $\left(\Delta \epsilon_{\mathrm{p}}\right)$. The nonrecoverable components may be attributed to the plastic deformation of the soil grain structure brought about by the failure of grain contacts under stress. The plastic, nonrecoverable components of pore pressure $\left(\Delta U_{p}\right)$ and axial strain $\left(\Delta \epsilon_{p}\right)$ continue to increase with time under repeated load although the elastic, recoverable components $\left(\Delta U_{\mathrm{e}}\right.$ and $\left.\Delta \epsilon_{\mathrm{e}}\right)$ remain almost constant.

The buildup of pore pressures and the increase in axial strains with time are shown for repeated loading tests in Figs. 2 and 3 . For simpiicity only the points for the 'load on' condition are shown; the 'load off' curves are generally identical but displaced by a constant value of strain and pore water pressure.

For small values of repeated deviator stress (i.e. less than about $0.37 \sigma_{\mathrm{s}}$ ), the pore pressures and strains are small and mainly of a recoverable nature. This may be termed the region of elastic behavior of the soil. For values of repeated stress greater than about $0.37 \sigma_{\mathrm{s}}$, the pore pressures and strains increase out of proportion to the applied stress as the nonrecoverable components of pore water pressure and strain become larger. This may be termed the region of plastic behavior of the soil.

\section{The Pore Water Pressure and Strain Relationship}

Figure 4 shows the linear relationship between pore pressures and strains. This graph is typical of all the tests with repeated deviator stresses in the 'elastic' range. The elastic recoverable components are represented by the lines joining the load off and load on points. The plastic, nonrecoverable components are represented by the line joining the load off points.

The recoverable component of pore water pressure $\left(\Delta U_{\mathrm{e}}\right)$ is proportional to the recoverabie $\left(\Delta \epsilon_{\mathrm{e}}\right)$ and the nonrecoverable component of pore water pressure $\left(\Delta U_{\mathrm{p}}\right)$ is proportional to the nonrecoverable component of strain 


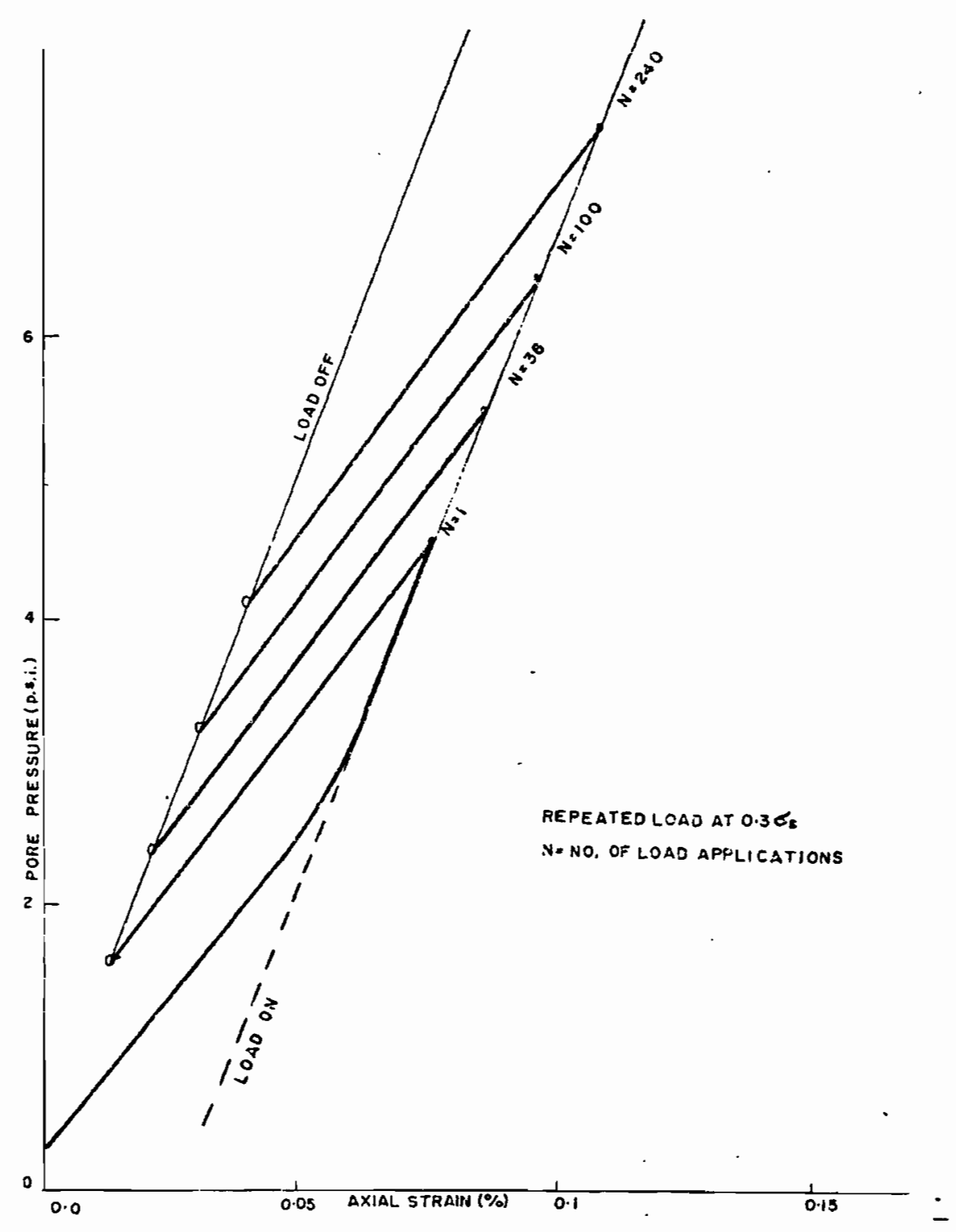

FIO. 4. Pore pressures versus strain relationships.

$\left(\Delta \varepsilon_{p}\right)$ but with a different constant of proportionality.

$$
\text { i.e. } \begin{aligned}
\Delta U_{\mathrm{e}} & =K_{1} \Delta \varepsilon_{\mathrm{e}} \\
\Delta U_{\mathrm{p}} & =K_{2} \Delta \varepsilon_{\mathrm{p}}
\end{aligned}
$$

This relationship is true for applied deviator stresses in the 'elastic' range. The results are in agreement with the pore pressure versus strain relationship hypothesized by Lo (1969).

Pore pressure and strain curves are shown for all repeated loading tests in Fig. 5; for convenience only the 'load on' foints are included. For applied stresses above the elastic range, the curves begin to curve away from the linear. This is probably due to the commencement of shearing between the individual soil grains, accompanied by the continuing process of grain structure collapse under load.

\section{Elastic Rebound}

Within the 'elastic' range of stresses, the recoverable strains and pore pressures are consistent with elastic theory; i.e. $\Delta \epsilon_{\mathrm{e}} \propto \sigma_{\mathrm{r}}$ and $\Delta U_{\mathrm{e}}=\frac{1}{3} \sigma_{\mathrm{r}}$. At values of applied deviator stress above the elastic range, the recoverable strains increase with subsequent load applications. This may be attributed to increases in the effective stress ratio $\left(\sigma_{1} / \sigma_{3}\right)$ as the nonrccoverable pore water pressure increases.

\section{Stress Paths}

The changes in the principal effective stresses occurring under a sustained or repeated load 


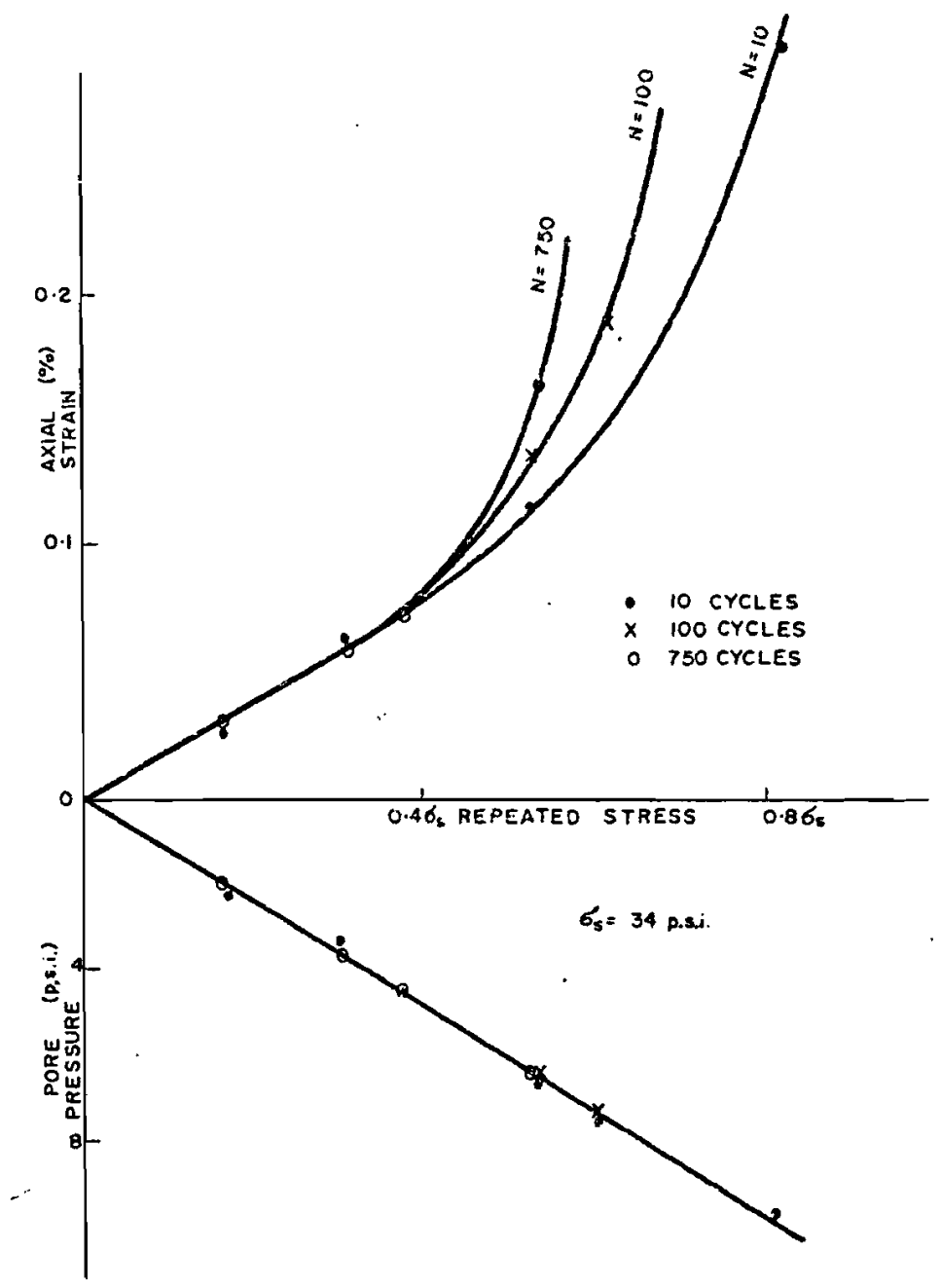

FIG. 5. Elastic and plastic ranges of repeated loadings.

may be represented on a stress diagram such as the Renduilic plot (Fig. 6) where the major rincipal effective stress $\sigma_{1}$ is plotted against the 1...nor principal effective stress $\sigma_{3}$ multiplied by $\sqrt{2}$. The test samples were subjected to isotropic consolidation of 50 p.s.i. $\left(3.5 \mathrm{~kg} / \mathrm{cm}^{2}\right)$. Under sustained loading the pore water pressure increases with the stress path moving towards the failure envelope; if the load is removed the state of effective stress returns to a point on the $\overline{\sigma_{1}}=\overline{\sigma_{3}}$ line. On this diagram a stress path moving towards the origin and parallel to the $\bar{\sigma}_{1}=\overline{\sigma_{3}}$ line is the result of pore pressures developed due to the failure of soil grain contacts (i.e. $\Delta U_{\mathrm{r}}$ component). A sample subjected to a repeated load eventually fails at a lower applied stress than the sample subjected to a sustained load of of the same magnitude. The actual value of the failure stress depends on the duration of loading cycles.
For practical purposes the variations in the stress paths under different loading conditions must be considered. The time in which the soil behaves in the undrained state is also an important factor in stability calculations; consolidation, of course, increases the factor of safety against failure.

\section{Comparisons with Remolded Clay}

The stress path for a sample which was remolded at the liquid limit, then consolidated such that the water content is similar to the natural consolidated samples, is also shown in Fig. 6. It may be seen that the stress path of the remolded sample almost coincides with the states of stress of samples at failure after a period of sustained or repeated loading. This suggests that the loading of a sensitive clay tends to break down the sensitivity until the soif behaves in a manner similar to the remolded 


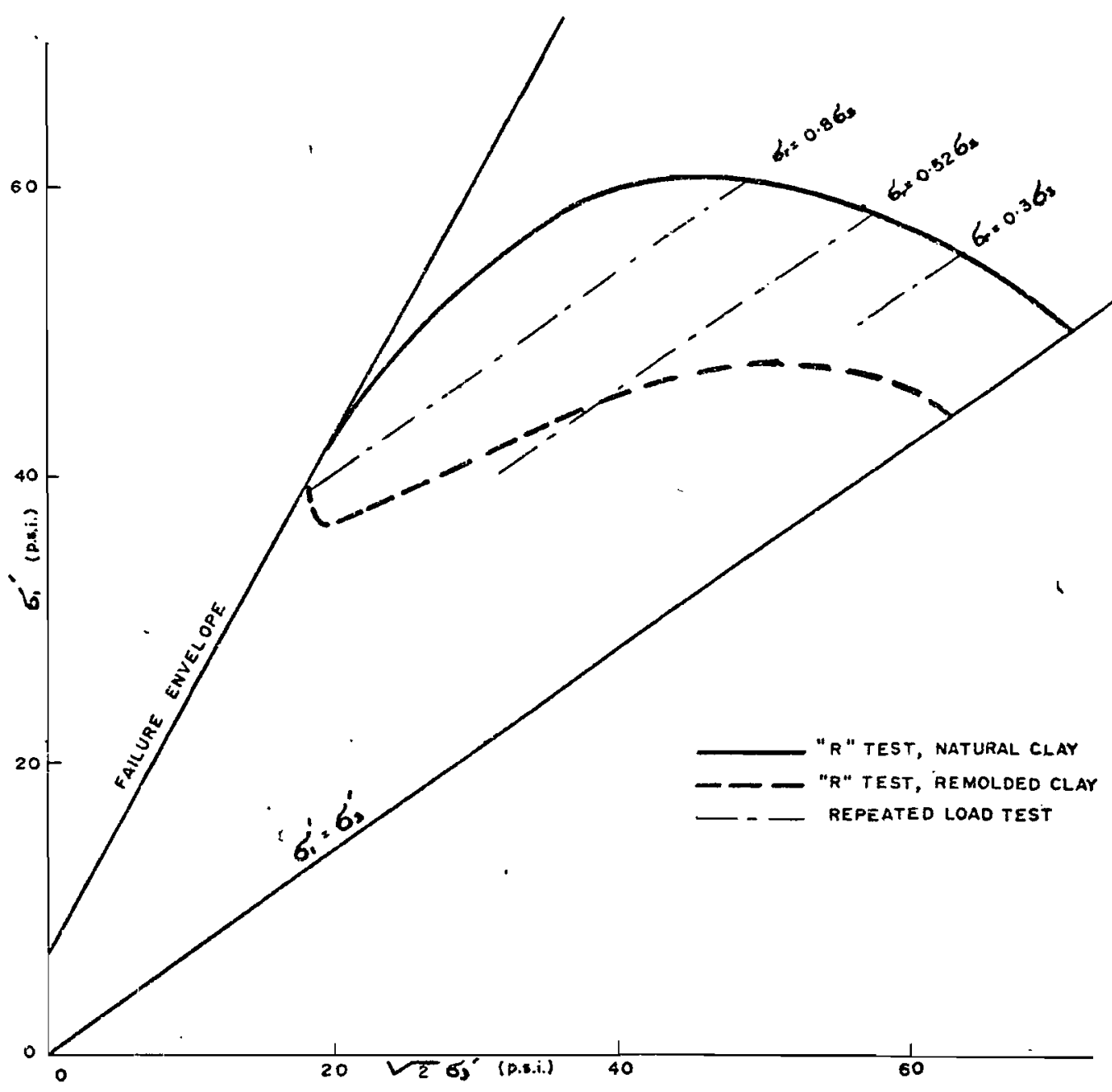

FIG. 6. Rendulic plot.

sample. This is consistent with the mechanism of failure of bonds at the grain contacts. In the natural clay, bonds exist at the grain contact points and some of these are broken by the loading. Remolding destroys the bonds and, therefore, strains and corresponding pore water pressures occur almost immediately on application of the load.

\section{Conclusions}

The effects of loading a saturated clay may be studied by considering separately the elastic (recoverable) and plastic (nonrecoverabie) components of axial strains and induced pore pressures. Repeated loading has been successfully used to separate these two components.

When a snall deviator strcss is applied (less than about $0.37 \sigma_{\mathrm{s}}$ for the clay under test), the soil behaves in a predominantly elastic manner. The elastic components of strain $\left(\Delta \varepsilon_{*}\right)$ and pore pressure $\left(\Delta U_{\mathrm{e}}\right)$ have been shown to be consistent with the elastic theory for saturated soils. The plastic strains $\left(\Delta \epsilon_{p}\right)$ and pore pressures $\left(\Delta U_{\mathrm{p}}\right)$ increase with time under load and have been otherwise recognized as creep. The plastic pore pressure components $\left(\Delta U_{n}\right)$ are directiy proportional to the plastic strains $\left(\Delta \epsilon_{p}\right)$ of the soil; this supports the hypothesis that plastic straining of the soil under small applied stresses is caused by the failure of bonds at the grain to grain contacts causing a partial collapse of the soil grain structure. The transfer of stress, previously carried by the grain contact, to the pore water causes an increase in pore pressures.

When a large deviator stress is applied (greater than about $0.37 \sigma_{\mathrm{s}}$ for the clay tested), the plastic components of strain and pore water pressure increase out of proportion to the applied stress. The process of collapse of the 
grain structure, with resulting increases in the plastic strains $\left(\Delta \epsilon_{\mathrm{p}}\right)$ and pore pressures $\left(\Delta U_{\mathrm{p}}\right)$, is complicated by sliding of the soil grains and dilatancy effects. For large deviator stresses, repeated loading increases the rate of straining and pore pressure generation over that of a sustained load. It is thought that the extra energy input of the repeated load rapidly overcomes the shearing resistance of the soil.

The effective stress state (Rendulic plot) for the soil sample after a period of time under repeated loading is very close to the stress path for a strength test on a remolded sample at the same water content; this suggests that the collapse of the soil structure is, in effect, partly remolding the soil.

The investigation has shown that the behavior of sensitive clays is greatly affected by the type if loading applied; there is no. unique effective stress path for a given soil sample. In practical cases, stress paths should be used which are appropriate to the conditions of loading and drainage in the field. There are many examples of repeated loading conditions in the fieldsuch as embankments, runways, wind effects on structures, etc.--where the strains and pore pressures should be maintained in the predominantly elastic range, with the consequent major increase in factor of safety required.

\section{Acknowledgments}

This research, conducted by the junior author under the supervision of the senior author, was conducted as part of the graduate research program at McMaster University (Greenwood 1970). The research was sponsored by the National Research Council of Canada and the Defence Research Board of Canada.

Bjerrum, L.. Simons, N., and TorblaA; 1. 1958. The effect of time on the shear strength of soft clay. Proc. Brussels Conf. Earth Pressure Problems, 1, pp. $148-158$.

Casagrande, A., and Wilson, S. D. 1951. Effect of rate of loading on the strength of clays and shales at constant water content. Geotechnique, 2(3), pp. 251-263.

CRAWFORD. C. B. 1959. The influence of rate of strain on effective stresses in sensitive clays. A.S.T.M., S.T.P. 254 , pp. 36-45.

GREENwOOD. J. R. 1970. Shear strength of clays after repeated loading. M.Eng. thesis, McMaster University, Hamilton. Ont.

Lo. K. Y. 1969. Pore pressure - strain relationship for normally consolidated undisturbed clays. Can. Geotech. J. 6(4), pp. 383-412.

Sangrey. D. A.. Henkel, D. J., and Esrig, M. J. 1969. The effective stress response of a saturated clay soil to - repeated loading. Can. Geotech.J. 6(3), pp. 241-252.

SEED, H. B.. and CHAN. C. K. 1961. Effect of duration of stress appiication on soil deformation under repeated loading. Proc. 5th Int. Conf. Soil Mech. Found: Eng., Dunod. Paris. pp. 341-346.

WALKER. L. K. 1969. Undrained creep in a sensitive clay. Geotechnique, 19 (4), pp. 515-529. 